mgr Lidia Derfert-Wolf

Uniwersytet Technologiczno-Przyrodniczy w Bydgoszczy

lidka@utp.edu.pl

\title{
ŹRÓDŁA DOCHODÓW BIBLIOTEK AKADEMICKICH ORAZ INNE WSKAŹNIKI FINANSOWE W PROJEKCIE AFBN
}

\author{
SOURCES OF FUNDS IN THE ACADEMIC LIBRARIES \\ AND OTHER FINANCIAL INDICATORS IN THE PARL PROJECT
}

\begin{abstract}
Abstrakt
W artykule przedstawiono stan obecny projektu Analiza Funkcjonowania Bibliotek Naukowych (AFBN), w którym uczestniczy ponad 60 bibliotek szkół wyższych w Polsce. Omówiono gromadzone dane z obszaru finansów oraz obliczane na ich podstawie wskaźniki funkcjonalności. Zaprezentowano uśrednione wartości wybranych wskaźników, z podziałem na typy uczelni najliczniej reprezentowanych w AFBN (uniwersytetów, uczelni o profilu technicznym i medycznym).
\end{abstract}

Słowa kluczowe: statystyka biblioteczna, wskaźniki funkcjonalności, AFBN, biblioteki akademickie, finanse bibliotek, źródła finansowania.

\begin{abstract}
The paper presents the current state of the project Performance Analysis for Research Libraries (PARL), which consists of more than 60 libraries of the higher education institutions in Poland. It discusses the financial data and the performance indicators calculated based on it. It also presents the average values of the selected indicators, with the division of the higher education institutions that are most frequently represented in PARL (universities, universities of technology and medical universities).
\end{abstract}


Keywords: library statistics, performance indicators, AFBN, PARL, academic libraries, library finance, sources of funds.

\section{Wprowadzenie - o projekcie AFBN}

Projekt Analiza Funkcjonowania Bibliotek Naukowych (AFBN), którego głównym celem jest wypracowanie standardów dla bibliotek szkół wyższych w Polsce, realizuje od 2001 r. Zespół ds. Standardów dla Bibliotek Naukowych (ZSBN), składający się z przedstawicieli sygnatariuszy „Porozumienia o współpracy”, podpisanego w 2004 r. ${ }^{2}$ Prace ZSBN zostały wpisane do zadań Konferencji Dyrektorów Bibliotek Akademickich Szkół Polskich (KDBASP), a koordynatorem AFBN jest Biblioteka Uniwersytecka w Poznaniu. Cel projektu jest realizowany, m.in. poprzez: pozyskiwanie danych statystycznych i obliczanie wskaźników funkcjonalności, zbiorczą analizę danych bibliotek, publikowanie rocznych raportów oraz rekomendowanie wskaźników organizatorom bibliotek, twórcom rankingów oraz innym instytucjom. Należy podkreślić, że pomimo realizacji projektu przez określony zespół osób, do efektów jego działania najbardziej przyczyniają się wszystkie biblioteki dostarczające corocznie dane statystyczne, na zasadzie dobrowolności.

W 2015 r. podpisano dokumenty o współpracy z przedstawicielami bibliotek publicznych i pedagogicznych oraz Stowarzyszeniem Bibliotekarzy Polskich w ramach projektu Analiza Funkcjonowania Bibliotek (AFB) ${ }^{3}$. Celem AFB jest opracowanie i wdrożenie jednolitych metod oraz narzędzi systematycznej oceny działania bibliotek naukowych, pedagogicznych i publicznych w oparciu o międzynarodowe normy i doświadczenia bibliotek zagranicznych. Należy dodać, że prace AFBN od początku bazowały na międzynarodowych normach z zakresu statystyki bibliotecznej i wskaźni-

1 Porozumienie o wspótpracy [AFBN]. Poznań 2012. Tryb dostępu: http://pliki.sbp.pl/afb/ AFBN_Porozumienie_2012.pdf [2 sierpnia 2017].

2 Porozumienie o współpracy z 2012 r. podpisały następujące instytucje: Akademia Górniczo-Hutnicza w Krakowie, Główna Biblioteka Komunikacyjna, Politechnika Krakowska, Uniwersytet Ekonomiczny w Krakowie, Uniwersytet im. Adama Mickiewicza w Poznaniu, Uniwersytet Technologiczno-Przyrodniczy w Bydgoszczy, Wojewódzka i Miejska Biblioteka Publiczna w Zielonej Górze, Wyższa Szkoła Biznesu - National-Louis University w Nowym Sączu.

3 Analiza Funkcjonowania Bibliotek: wskaźniki efektywności i dane statystyczne. Tryb dostępu: http://afb.sbp.pl/ [2 sierpnia 2017]. 
kach funkcjonalności ${ }^{4}$, a zestaw gromadzonych danych i wskaźników weryfikuje się w oparciu o kolejne edycje norm.

AFBN realizuje zadania za pomocą aplikacji sieciowej składającej się z formularza online do przekazywania danych statystycznych przez biblioteki oraz bazy, w której na podstawie zgromadzonych danych automatycznie obliczane są i analizowane wskaźniki funkcjonalności. Wymagane w formularzu dane są precyzyjnie objaśnione oraz zaopatrzone w informacje o ich zgodności z danymi przekazywanymi do GUS-u. Ponadto w aplikacji funkcjonuje system ostrzegania o błędach, pomocny przy wstępnej weryfikacji wprowadzanych danych. Kolejny etap sprawdzania realizowany jest przez osoby upoważnione przez ZSBN, które kontaktują się z wypełniającymi formularze w celu ustalenia poprawności danych.

Wyniki badań $\mathrm{w}$ postaci tabel $\mathrm{z}$ uśrednionymi wartościami wskaźników dla poszczególnych typów bibliotek na przestrzeni lat oraz wszelkie przydatne informacje prezentowane są na witrynie projektu ${ }^{5}$. Należy dodać, że dyrektorzy zarejestrowanych bibliotek mają możliwość wieloaspektowego analizowania danych i wskaźników swoich placówek oraz porównywania swoich wyników z uśrednionymi rezultatami bibliotek z danej grupy (np. politechnik) według czterech miar (średnia arytmetyczna, mediana, wartość maksymalna i minimalna).

W bazie danych AFBN zarejestrowanych jest 71 bibliotek szkół wyższych $^{6}$, przy czym nie wszystkie $\mathrm{z}$ nich wypełniają każdego roku formularze, których zatwierdzenie przez administratora warunkuje udział w badaniach. Dane z 2015 r. wprowadziło 58 bibliotek uczelni publicznych (w tym: 21 uczelni technicznych, 19 uniwersytetów, 10 uczelni medycznych, 3 ekonomiczne, 2 wychowania fizycznego, 3 artystyczne) oraz 5 bibliotek uczelni niepublicznych.

4 Najnowsze edycje tych norm to: PN-ISO 2789:2016 Informacja i dokumentacja. Międzynarodowa statystyka biblioteczna, ISO 11620:2014 Information and documentation. Library performance indicators.

5 Analiza Funkcjonowania Bibliotek Naukowych: wskaźniki efektywności i dane statystyczne. Tryb dostępu: http://afb.sbp.pl/afbn/ [2 sierpnia 2017].

6 W latach 2002-2012 w badaniach uczestniczyło kilka bibliotek publicznych posiadających status bibliotek naukowych oraz bibliotek branżowych. Ze względu na powstanie projektu Analiza Funkcjonowania Bibliotek Publicznych oraz na niskie zainteresowanie badaniami wśród bibliotek branżowych, od 2013 r. w bazie AFBN rejestrowane są tylko biblioteki szkół wyższych (publicznych i niepublicznych). 


\section{Dane i wskaźniki finansowe w AFBN}

Dane statystyczne gromadzone przez biblioteki są wybrane spośród danych zalecanych do zbierania przez normy międzynarodowe oraz danych obowiązkowo przekazywanych do GUS-u. Dotyczą one wszystkich obszarów działalności bibliotek: pracowników, użytkowników, zbiorów, finansów, infrastruktury, świadczonych usług i ich wykorzystania oraz innych przedsięwzięć (np.: tworzonych baz danych, wydawnictw własnych czy konserwacji zbiorów) ${ }^{7}$. Jeśli chodzi o dane finansowe, to $\mathrm{w}$ formularzu występują dwa rozbudowane pytania - źródła finansowania biblioteki w PLN i wydatki na funkcjonowanie biblioteki w PLN - oraz jeden wskaźnik, mianowicie budżet biblioteki jako procent budżetu uczelni ${ }^{8}$.

W pytaniu o finansowanie działalności, biblioteki podają wartości bezwzględne przychodów brutto, bez względu na ich pochodzenie, a w tym: fundusz przyznawany przez jednostkę nadrzędną na działalność bieżącą (w tym fundusz płac), dotacje $\mathrm{z}$ innych źródeł, środki finansowe wypracowane przez bibliotekę i pozostałe. Fundusz przyznawany przez jednostkę nadrzędną to środki finansowe, które biblioteka - jako jednostka uczelniana - otrzymuje na działalność bieżącą (np.: płace, zakup zbiorów, utrzymanie), z wykluczeniem środków inwestycyjnych. Dotacje z innych źródeł to środki pozyskane z zewnętrznych źródeł publicznych, które biblioteka może otrzymywać w formie grantu, dotacji celowej, dofinansowania, itp. W tych środkach uwzględnia się fundusze przeznaczone zarówno na działalność bieżącą, jak również specjalne zadania w danym roku (np.: dotacje innych jednostek uczelni na prenumeratę czasopism i baz danych, dotacje rządowe, resortowe) czy specjalne inwestycje (np.: zakup sprzętu, systemu zintegrowanego, wyposażenia magazynów, pomieszczeń bibliotecznych, budowy itp.).

Z kolei pytanie dotyczące wydatków na funkcjonowanie biblioteki zawiera szereg pytań szczegółowych obejmujących koszty: zakupu i prenumeraty zbiorów (drukowanych książek polskich i zagranicznych, drukowanych czasopism polskich i zagranicznych, zbiorów specjalnych oraz zasobów elektronicznych), zakupu sprzętu komputerowego i oprogramowania, zakupu wyposażenia, wynagrodzeń i innych świadczeń z tytułu pracy,

7 Wzór formularza danych statystycznych AFBN dostępny jest pod adresem: http://pliki. sbp.pl/afb/afbn/formularz_wzor_szkoly_wyzsze_2016.pdf.

8 Wskaźnik „budżet biblioteki jako procent budżetu uczelni” jest jedynym wskaźnikiem podawanym przez biblioteki. Pozostałe obliczane są automatycznie $\mathrm{w}$ bazie danych, na podstawie zgromadzonych danych statystycznych. 
usług i administrowania, szkolenia personelu, utrzymania pomieszczeń i remontów, promocji, amortyzacji itp.

Wskaźniki funkcjonalności biblioteki służą do charakterystyki efektywności dostarczania przez bibliotekę usług oraz wydajności przeznaczania i wykorzystywania zasobów (w tym środków finansowych) w celu świadczenia tych usług. Wskaźniki te są wyrażeniami liczbowymi, symbolicznymi lub słownymi zaczerpniętymi ze statystyki bibliotecznej i innych danych (np. otrzymywanych na podstawie badań ankietowych) ${ }^{9}$. Mierniki w AFBN obliczane są automatycznie na podstawie zgromadzonych w bazie danych statystycznych. Definicje i metody obliczania większości z nich zaczerpnięto z normy międzynarodowej ${ }^{10}$. Wskaźniki (łącznie $106^{11}$ ) podzielono w następujące grupy:

- wskaźniki ogólne (15);

- wskaźniki finansowe (35);

- wskaźniki dotyczące zbiorów (20);

- $\quad$ wskaźniki dotyczące korzystania z usług, np. wypożyczenia, usługi informacyjne, szkolenia (23);

- wskaźniki dotyczące pracowników $(13)^{12}$.

Dość duża liczba wskaźników w porównaniu z projektami w innych krajach $^{13}$ wynika $\mathrm{z}$ potrzeby podawania wielu $\mathrm{z}$ nich $\mathrm{w}$ odniesieniu do trzech kategorii osób: użytkownika ${ }^{14}$, studenta ${ }^{15}$ i studenta studiów stacjonarnych. Należy dodać, że dzięki mechanizmowi automatycznego obliczania wskaźników, ich liczba nie ma żadnego wpływu na zwiększenie wysiłku osób gromadzących dane w poszczególnych bibliotekach.

9 PN-ISO 11620:2012 Informacja i dokumentacja. Wskaźniki funkcjonalności bibliotek.

10 Tamże; ISO 11620:2014..., dz. cyt.

11 Cztery wskaźniki są podawane przez biblioteki: czas przysposobienia książki, budżet biblioteki jako procent budżetu uczelni, liczba godzin (w tygodniu), w których dostępne są usługi biblioteczne, usługi sieciowe i/lub interaktywne.

12 Wskaźniki funkcjonalności dla bibliotek szkół wyższych (2016 r.). Tryb dostępu: http://pliki.sbp.pl/afb/afbn/AFBN_wskazniki_2016_portal.pdf [2 sierpnia 2017].

13 L. Derfert-Wolf, M. Górski, A. Jazdon: Finansowanie bibliotek uczelni publicznych. Analiza wybranych wskaźników z lat 2002-2007. „Biuletyn EBIB” 2009, nr 8(108). Tryb dostępu: http://www.ebib.info/2010/108/a.php?derfert_gorski_jazdon [2 sierpnia 2017].

14 Liczba użytkowników oznacza w AFBN łączną liczbę studentów studiów stacjonarnych, studentów studiów niestacjonarnych i słuchaczy studiów podyplomowych oraz pracowników uczelni.

15 Liczba studentów oznacza w AFBN łączną liczbę studentów studiów stacjonarnych oraz studentów studiów niestacjonarnych i słuchaczy studiów podyplomowych. 
Wśród wskaźników finansowych (zob. załącznik 1.) znajdziemy mierniki dotyczące:

- $\quad$ wydatków biblioteki ogółem bądź wybranych wydatków (np. na zbiory), w przeliczeniu na wymienione wyżej trzy kategorie użytkowników;

- odsetka poszczególnych kategorii źródeł finansowania w stosunku do wszystkich środków finansowych biblioteki oraz budżetu biblioteki jako procent budżetu uczelni;

- odsetka poszczególnych kategorii wydatków w stosunku do bieżących wydatków na funkcjonowanie biblioteki;

- kilku istotnych kosztów w odniesieniu do świadczonych usług (np. odwiedzin biblioteki).

\section{Wybrane wyniki badań z lat 200x2-2015 ${ }^{16}$}

Pierwszym czynnikiem rzutującym na zakres omawianych danych i wskaźników jest fakt, że wśród placówek zarejestrowanych w AFBN najliczniej reprezentowane są biblioteki trzech typów uczelni publicznych - uniwersytetów, uczelni technicznych i medycznych - i właściwie tylko w odniesieniu do tych grup można mówić o miarodajności rezultatów. W związku z tym, wyniki badań przedstawiono dla wszystkich bibliotek publicznych szkół wyższych, a w niektórych przypadkach dodatkowo z podziałem na wymienione trzy typy bibliotek.

Kolejnym czynnikiem mającym istotny wpływ na obszar prezentowanych wyników badań jest zakres czasowy. Wskaźniki prezentowane w odniesieniu do wszystkich badanych bibliotek uczelni publicznych zaprezentowano w pełnym zakresie, tj. 2002-2015. Biblioteki uczelni medycznych uczestniczą w badaniach od 2004 r., w związku z czym porównania trzech grup bibliotek dokonywano w zakresie 2004-2015. Ograniczony zakres dotyczy również nowych wskaźników, dodawanych w kolejnych latach realizacji projektu.

Przedstawiając wyniki badań skoncentrowano się na kluczowych wskaźnikach z punktu widzenia zarządzania finansami oraz efektywności kosztowej bibliotek ${ }^{17}$. Omówiono przychody bibliotek, uwzględniając

16 Autorka składa podziękowanie Markowi M. Górskiemu za wsparcie w zgromadzeniu danych źródłowych analizowanych w niniejszym artykule.

17 Szczegółowe analizy wszystkich wskaźników, z podziałem na grupy bibliotek oraz na przestrzeni lat znaleźć można na stronie: http://afb.sbp.pl/afbn/wyniki-badan. 
różne źródła finansowania oraz wydatki na główne obszary funkcjonowania biblioteki. Zaprezentowano również wskaźniki określające wydatki na zbiory w przeliczeniu na jednego użytkownika, koszt funkcjonowania $\mathrm{w}$ przeliczeniu na odwiedziny w bibliotece oraz koszt skorzystania ze zbiorów. Do prezentacji wyników badań wybrano najbardziej reprezentatywną miarę - medianę, której obliczanie eliminuje wartości skrajne, w przeciwieństwie do średniej arytmetycznej.

Analizę wybranych wyników badań w obszarze finansów bibliotek rozpoczniemy od przedstawienia wartości procentowego udział budżetów bibliotek w budżecie uczelni (wykres 1.). W latach 2004-2015 wartość tego wskaźnika jest w miarę ustabilizowana i dla wszystkich bibliotek uczelni publicznych oscyluje w granicach 2,4-2,8\%, dla uniwersytetów jest to $2,9-4,2 \%$, dla bibliotek uczelni technicznych $1,7-2,6 \%$, a dla bibliotek uczelni medycznych 1,6-2,6\%.

Wykres 1. Budżet biblioteki jako procent budżetu uczelni - mediana z lat 2004-2015

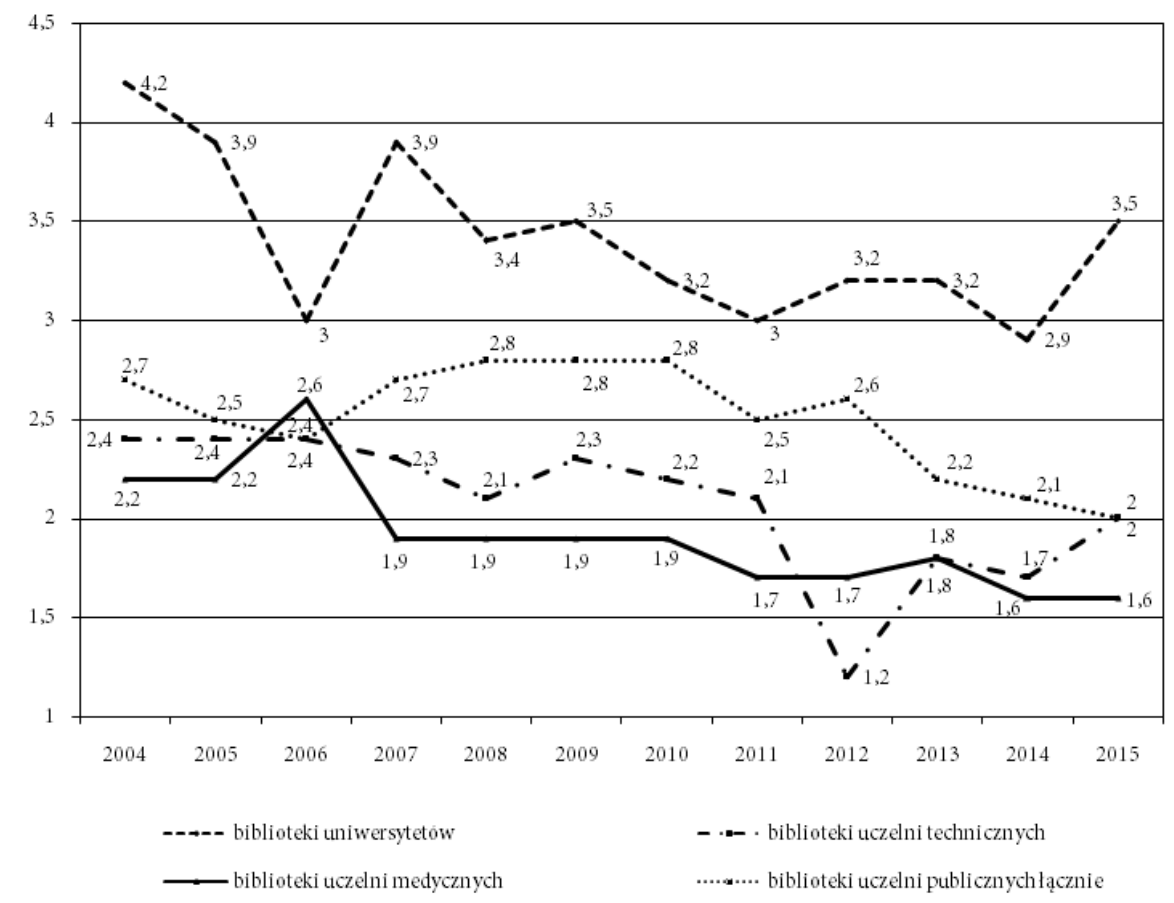

Źródło: opracowanie własne na podstawie danych z AFBN. 


\section{Wykres 2.Procentowy udział głównychźródełfinansowania bibliotek uczelni publicznych - mediana $\mathrm{z}$ lat 2002-2015}

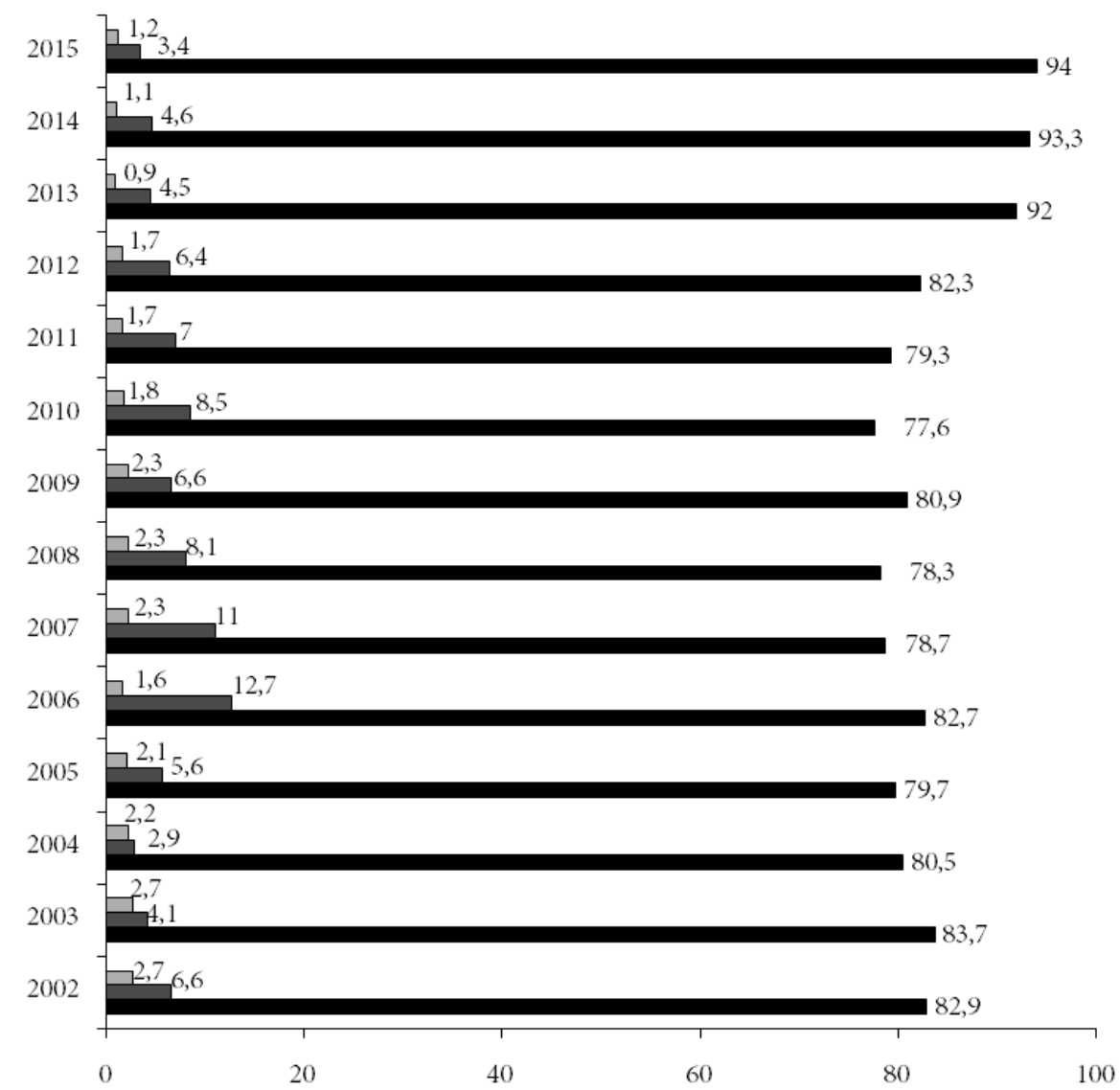

$\square$ środki finansowe wypracowaneprzez bibliotekę

$\square$ dotacjez innychźródeł

- fundusz przyznawany przez jednostkę nadrzędną na działal ność bieżącą (w tym fundusz płac)

Źródło: opracowanie własne na podstawie danych z AFBN.

Kolejną grupą analizowanych wskaźników jest procentowy udział poszczególnych źródeł finansowania bibliotek w ogólnej kwocie wpływów, biorąc pod uwagę: fundusz przyznawany przez jednostkę nadrzędną, pozyskane dotacje (np.: fundusze UE, DUN, granty celowe itp.), środki wypracowane przez bibliotekę oraz pozostałe środki, nie mieszczące się w wyżej wymienionych kategoriach. Medianę źródeł finansowania wszystkich bada- 
nych bibliotek publicznych w latach 2002-2015 przedstawiono na wykresie 2. Nie uwzględniono na nim mediany tzw. pozostałych środków, która przeciętnie w badanym okresie wynosi $0,1 \%$.

Analizując trendy można jednoznacznie stwierdzić, że biblioteki funkcjonują głównie dzięki środkom przyznanym przez macierzystą uczelnię (od 82,9\% w 2002 r., poprzez 77,6\% w 2010 r., aż do 94\% w 2015 r.). Mediana wskaźnika „dotacje z innych źródeł” (dotacje celowe, granty itp.) we wszystkich badanych bibliotekach osiąga przeciętnie niewielki odsetek (6,6\%), ale cechuje się zróżnicowanymi wartościami w poszczególnych latach, np. aż 12,7\% w 2006 r., a zaledwie 3,4\% w 2015 r. Można to z pewnością uzasadnić faktem, że w tej kategorii przychodów mieszczą się środki inwestycyjne przeznaczone na specjalne zadania w poszczególnych latach. Należy też przypomnieć, że choć prezentowane mediany nie uwzględniają skrajnych wartości minimalnych i maksymalnych, odbiegających mocno od średniej, to w danych surowych poszczególnych grup bibliotek pojawiają się wskaźniki odzwierciedlające bardzo wysoki odsetek środków ze źródeł zewnętrznych, np. na budowę biblioteki. Z kolei środki finansowe wypracowane przez bibliotekę (np. opłaty za niedotrzymanie terminu zwrotu książek, opłaty za wynajęcie powierzchni) stanowią przeciętnie 1,9\% wpływów w latach 2002-2015 i odsetek ten pozostaje na wyrównanym poziomie, osiągając najwyższą wartość mediany $2,7 \%$ w 2002 r., a najniższą $0,9 \%$ w 2013 r.

Należy tu podkreślić, że analizie źródeł finansowania poddano jedynie medianę wszystkich badanych bibliotek uczelni publicznych w poszczególnych latach. Zainteresowanych relacjami tych wskaźników w określonych typach bibliotek odsyłamy do szczegółowych wyników badań AFBN ${ }^{18}$. Dla przykładu można przytoczyć dane z 2015 r. I tak mediana odsetka funduszu przyznawanego przez jednostkę nadrzędną wynosi: w uniwersytetach $93,2 \%$, w uczelniach technicznych $92,3 \%$, a w uczelniach medycznych $97,2 \%$. Mediana odsetka dotacji pozyskanych z innych źródeł wynosi odpowiednio $5,2 \%, 3,9 \%$ i $0,6 \%$, a mediana odsetka środków wypracowanych przez bibliotekę: 1,3\%, 1,4\% i 0,9\%.

Analizując z kolei wydatki bibliotek uczelni publicznych z podziałem na kategorie należy podkreślić, że biblioteki podają szczegółowe kategorie kosztów (załącznik 1.), uwzględniając wyłącznie wydatki bieżące, bez kosz-

18 Analiza Funkcjonowania Bibliotek Naukowych: wskaźniki efektywności i dane statystyczne. Wyniki badań. Tryb dostępu: http://afb.sbp.pl/afbn/wyniki-badan [2 sierpnia 2017]. 
tów inwestycyjnych. Prezentując wskaźniki dokonano kumulacji tych danych w trzy podstawowe grupy kosztów: wydatki na zbiory (drukowane i elektroniczne), wydatki na wynagrodzenia i inne świadczenia $\mathrm{z}$ tytułu pracy oraz pozostałe wydatki obejmujące utrzymanie pomieszczeń, zakup sprzętu i wyposażenia, promocję, administrowanie, koszt amortyzacji itp.

\section{Wykres 3. Procentowy udział głównych kategorii wydatków bibliotek uczelni publicznych - mediana $z$ lat 2002-2015}

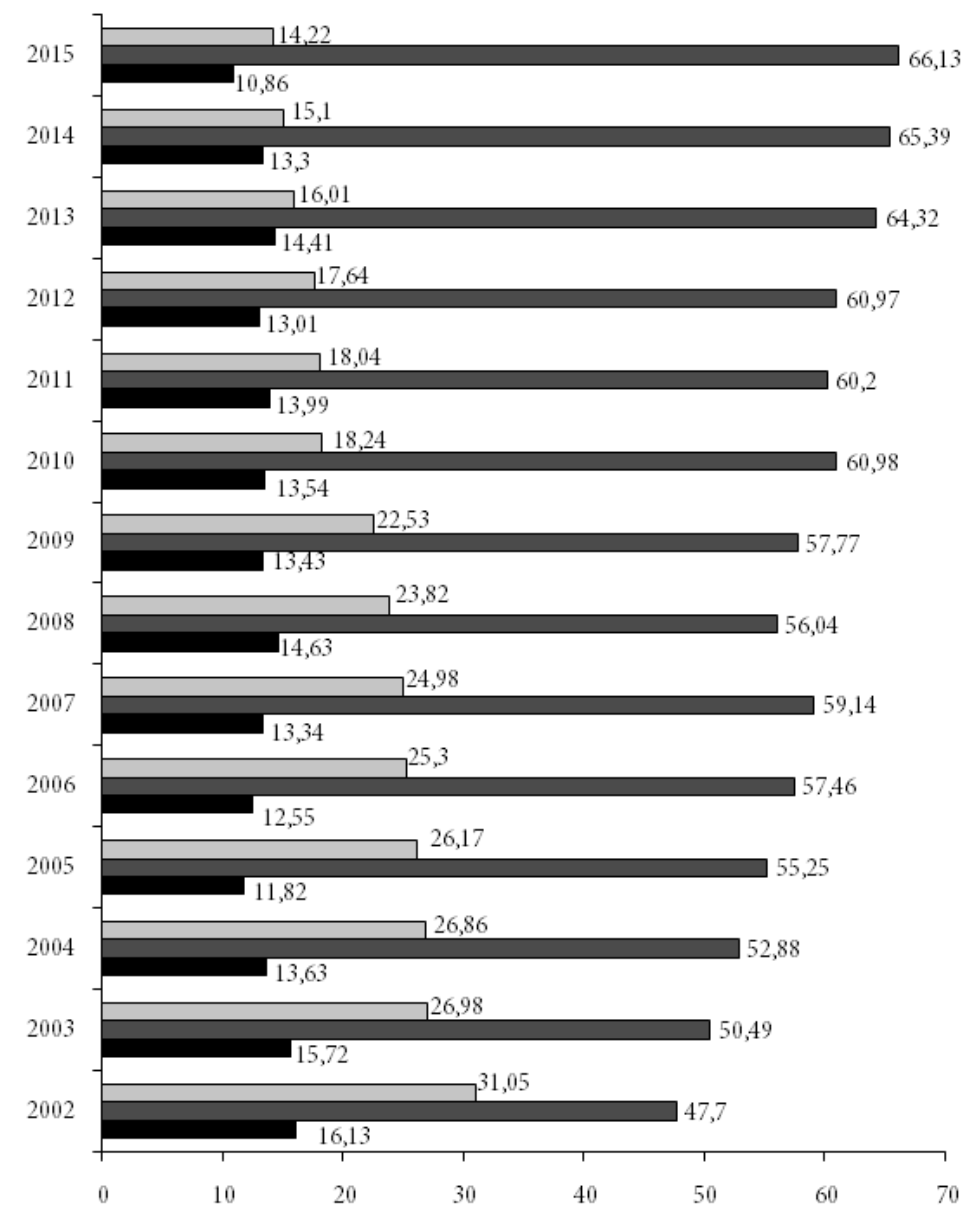

$\square$ wydatki na zbiory jako procent wydatków na funkcjonowa nie biblioteki

$\square$ wydatki na wynagrodzenia i inne świa dczenia z tytułupracy jako procent wydatków na funkcjonowaniebiblioteki

- pozostałewydatkijako procent wydatków na funkcjonowa niebiblioteki

Źródło: opracowanie własne na podstawie danych z AFBN. 
Podobnie jak w przypadku prezentacji źródeł finansowania bibliotek, analizie poddano jedynie medianę dla wszystkich badanych uczelni publicznych. Wartości wskaźników w określonych typach bibliotek, wartości bardziej szczegółowych kategorii wydatków (np. utrzymanie pomieszczeń) czy relacje pomiędzy nimi (np. wydatki na zasoby elektroniczne jako procent wydatków na zbiory biblioteczne) znaleźć można na witrynie AFBN ${ }^{19}$.

Dane przedstawione na wykresie 3. pokazują wyraźnie, że największy odsetek wydatków bieżących bibliotek uczelni publicznych stanowią koszty wynagrodzeń i pochodnych, przy czym wartość tego wskaźnika systematycznie rośnie. Skutkiem tego proporcjonalnie maleją odsetki wydatków na zbiory oraz pozostałe koszty. Jednocześnie należy zauważyć, że procent wydatków na zbiory w latach 2002-2009 wykazywał niewielką tendencję spadkową, obniżając się znacznie w 2010 r., w którym wszystkie biblioteki szkół wyższych mogły skorzystać z tzw. licencji krajowej na dostęp do wybranych zasobów elektronicznych, opłacany ze środków Ministerstwa Nauki i Szkolnictwa Wyższego.

Z pozostałych wskaźników finansowych przedstawimy te, które obrazują wydatki biblioteki w odniesieniu do użytkowników i do wykorzystania zbiorów. Poczynając od wskaźnika „wydatki biblioteki w przeliczeniu na użytkownika", przy obliczaniu którego bierze się pod uwagę sumę wydatków bieżących, zauważyć można wzrost jego wartości na przestrzeni lat. W 2015 r. wskaźnik ten w przypadku wszystkich bibliotek uczelni publicznych osiągnął wartość niemal dwukrotnie wyższą niż w 2002 r. (wykres 4.). Jednocześnie można zauważyć, że mediana tego wskaźnika w bibliotekach uczelni medycznych znacznie przewyższa wyniki pozostałych bibliotek, osiągając przeciętną kwotę 380 zł w latach 2004-2015, przy kwocie 244 zł we wszystkich badanych bibliotekach w tym samym okresie. Podobnie sytuacja ta wygląda w przypadku wskaźnika „wydatki na zbiory w przeliczeniu na użytkownika" (wykres 5.). Należy dodać, że w obliczeniach obydwu tych wskaźników bierze się pod uwagę tzw. potencjalnych użytkowników, co w przypadku bibliotek szkół wyższych oznacza studentów i pracowników uczelni. Dla oszacowania realnych kosztów usług bibliotecznych, należałoby dodatkowo obliczyć te wskaźniki w odniesieniu do aktywnie wypożyczających użytkowników, choć pomijamy tu tych użytkowników, którzy korzystają z innych usług, a nie wypożyczają książek.

19 Tamże. 
Wykres 4. Wydatki biblioteki w przeliczeniu na użytkownika w PLN mediana w latach 2004-2015

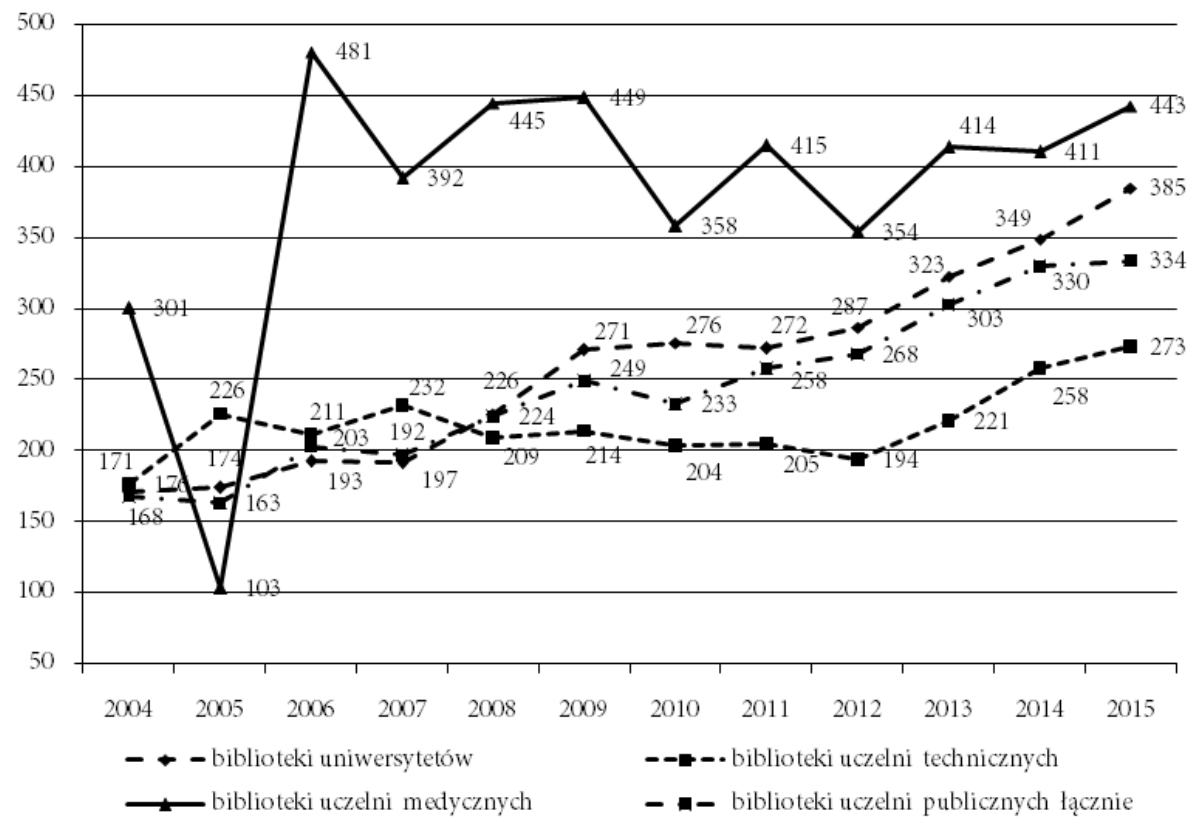

Źródło: opracowanie własne na podstawie danych z AFBN.

Od 2013 r. w AFBN obliczany jest nowy wskaźnik określający koszt biblioteki - biorąc pod uwagę sumę bieżących wydatków - w przeliczeniu na liczbę odwiedzin fizycznych w bibliotece. Koszt ten w widoczny sposób systematycznie rośnie, szczególnie dynamicznie w bibliotekach uczelni medycznych (tabela 1.). Podobnie sytuacja wygląda ze wskaźnikiem „koszt skorzystania ze zbiorów”, stanowiącym relację bieżących wydatków poniesionych na funkcjonowanie biblioteki w odniesieniu do łącznej liczby zrealizowanych usług bibliotecznych (wypożyczeń na zewnątrz wraz z prolongatami, udostępnień na miejscu, zrealizowanych zamówień na wypożyczenia międzybiblioteczne, liczby pobranych dokumentów z licencjonowanych czasopism elektronicznych i pełnotekstowych baz danych). W tym jednak przypadku dysproporcja pomiędzy bibliotekami uczelni medycznych a pozostałymi bibliotekami nie jest duża. Przyczyn należy szukać we wskaźnikach i danych dotyczących wykorzystania usług bibliotecznych. Okazuje się, że w 2015 r. biblioteki uczelni medycznych odnotowały przeciętnie 45 tys. odwiedzin, natomiast: biblioteki uniwersyteckie 126,4 tys., biblioteki uczelni technicznych - 82,5 tys. 
Wykres 5. Wydatki na zbiory w przeliczeniu na użytkownika w PLN mediana w latach 2004-2015

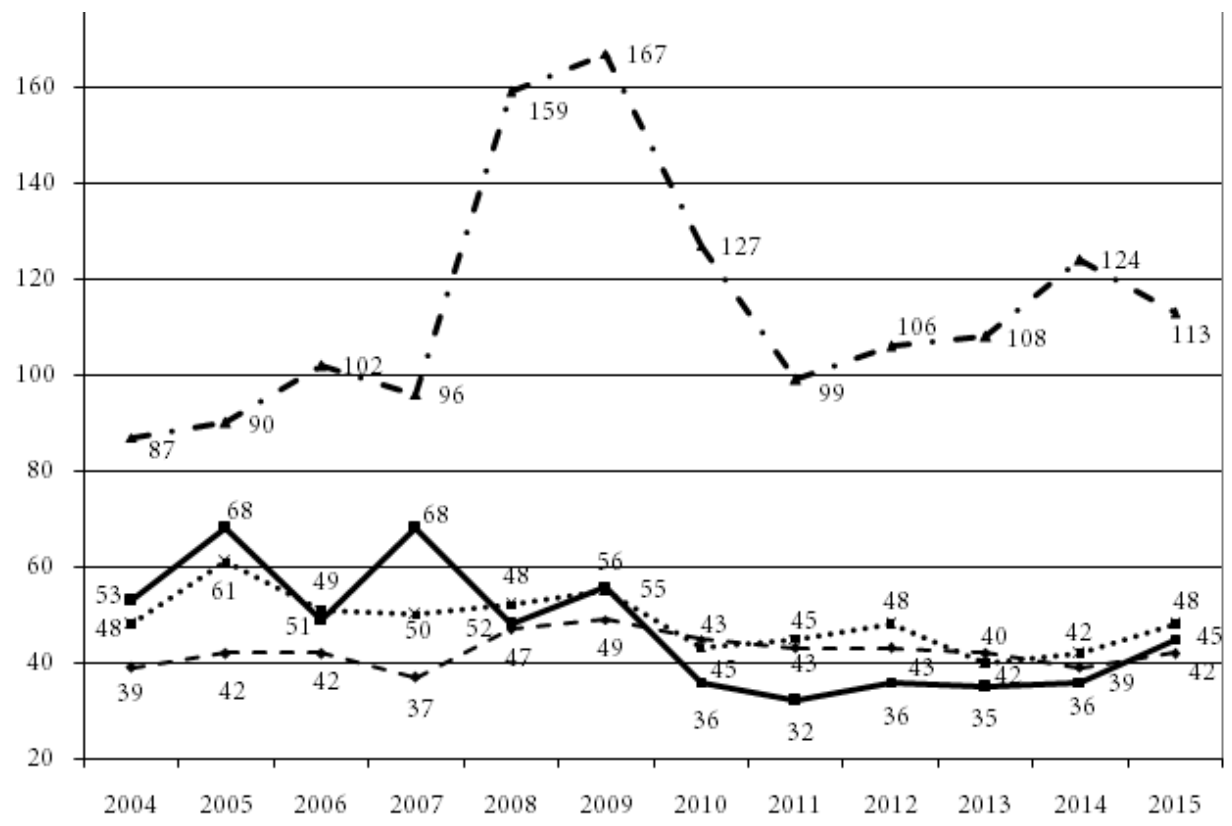

Źródło: opracowanie własne na podstawie danych z AFBN.

Tabela 1. Wskaźniki kosztów funkcjonowania bibliotek w latach 2013-2015 (mediany)

\begin{tabular}{|l|c|c|c|c|c|}
\hline \multirow{2}{*}{$\begin{array}{c}\text { Grupa bibliotek } \\
\text { Biblioteki uniwersytetów }\end{array}$} & \multicolumn{2}{|c|}{$\begin{array}{c}\text { Koszt w przeliczeniu } \\
\text { na odwiedziny w } \\
\text { bibliotece w PLN }\end{array}$} & $\begin{array}{c}\text { Koszt skorzysta- } \\
\text { nia ze zbiorów } \\
\text { w PLN* }\end{array}$ \\
\cline { 2 - 7 } & $\mathbf{2 0 1 3}$ & $\mathbf{2 0 1 4}$ & $\mathbf{2 0 1 5}$ & $\mathbf{2 0 1 4}$ & $\mathbf{2 0 1 5}$ \\
\hline Biblioteki uczelni technicznych & 36,1 & 42,6 & 49,5 & 10 & 9,5 \\
\hline Biblioteki uczelni medycznych & 45,2 & 46,7 & 48,7 & 11,5 & 11,2 \\
\hline $\begin{array}{l}\text { Biblioteki wszystkich badanych } \\
\text { uczelni publicznych }\end{array}$ & 47,6 & 85,6 & 130,4 & 12,4 & 13,3 \\
\hline
\end{tabular}

*Wskaźnik „koszt skorzystania ze zbiorów” jest obliczany od 2014 r.

Źródło: opracowanie własne na podstawie danych z AFBN.

\section{Wnioski}

Sto sześć wskaźników funkcjonalności (ogólnych, finansowych, dotyczących zbiorów, usług bibliotecznych oraz pracowników) wyliczanych 
w bazie AFBN stanowi bogate źródło danych o bibliotekach, dając możliwość dokonywania rozmaitych porównań, zestawień, śledzenia zmian i tendencji zachodzących w polskich bibliotekach szkół wyższych. Na potrzeby niniejszego artykułu przedstawiono jedynie kilka z grupy wskaźników finansowych. Dalsze szczegółowe analizy i interpretacje wyników, dokonywane również we własnym zakresie przez dyrektorów bibliotek zarejestrowanych w AFBN, powinny uwzględniać szerszy kontekst oraz relacje pomiędzy wskaźnikami. Do najważniejszych należą tu wskaźniki dotyczące odwiedzin w bibliotece, wypożyczeń itp.

Podsumowując, należy też stwierdzić, że miarodajność wyników badań na podstawie AFBN zależy od liczebności placówek uczestniczących w projekcie, które poza wpływaniem na wypracowywanie standardów funkcjonowania bibliotek, odnoszą też indywidualne korzyści z corocznego wypełnienia formularzy z danymi statystycznymi. Należą do nich głównie: automatyczne generowanie wskaźników efektywności, porównywanie wartości wskaźników własnej biblioteki z uśrednionymi danymi określonej grupy bibliotek, przeglądanie i analiza danych własnej biblioteki według różnych kryteriów i na przestrzeni lat, systematyczne gromadzenie i archiwizowanie danych w jednym miejscu oraz nieograniczony dostęp do danych własnej biblioteki.

\section{Bibliografia}

1. Analiza Funkcjonowania Bibliotek: wskaźniki efektywności i dane statystyczne. Tryb dostępu: http://afb.sbp.pl/ [2 sierpnia 2017].

2. Analiza Funkcjonowania Bibliotek Naukowych: wskaźniki efektywności i dane statystyczne. Tryb dostępu: http://afb.sbp.pl/afbn/ [2 sierpnia 2017].

3. Derfert-Wolf L., Górski M., Jazdon A.: Finansowanie bibliotek uczelni publicznych. Analiza wybranych wskaźników z lat 2002-2007. „Biuletyn EBIB” 2009, nr 8(108). Tryb dostępu: http://www.ebib.info/2010/108/a.php?derfert_gorski_ jazdon [2 sierpnia 2017].

4. Porozumienie o współpracy [AFBN]. Poznań 2012. Tryb dostępu: http://pliki. sbp.pl/afb/AFBN_Porozumienie_2012.pdf [2 sierpnia 2017].

5. PN-ISO 2789:2016 Informacja $i$ dokumentacja. Międzynarodowa statystyka biblioteczna.

6. PN-ISO 11620:2014 Information and documentation. Library performance indicators.

7. PN-ISO 11620:2012 Informacja i dokumentacja. Wskaźniki funkcjonalności bibliotek.

8. Wskaźniki funkcjonalności dla bibliotek szkół wyższych (2016 r.). Tryb dostępu: http://pliki.sbp.pl/afb/afbn/AFBN_wskazniki_2016_portal.pdf [2 sierpnia 2017]. 


\section{Załącznik 1}

Wskaźniki finansowe w projekcie $\mathrm{AFBN}^{20}$ :

- wydatki biblioteki w przeliczeniu na użytkownika/studenta/ /studenta studiów stacjonarnych w PLN;

- wydatki na zbiory biblioteczne w przeliczeniu na użytkownika/ /studenta/studenta studiów stacjonarnych w PLN;

- wydatki na książki drukowane w przeliczeniu na użytkownika/ /studenta/studenta studiów stacjonarnych w PLN;

- wydatki na zasoby elektroniczne w przeliczeniu na użytkownika/ /studenta/studenta studiów stacjonarnych w PLN;

- wydatki na sprzęt komputerowy i oprogramowanie w przeliczeniu na użytkownika/studenta/studenta studiów stacjonarnych w PLN;

- fundusz przyznawany przez jednostkę nadrzędną na działalność bieżącą (w tym fundusz płac) jako procent przychodów brutto;

- dotacje z innych źródeł jako procent przychodów brutto;

- środki finansowe wypracowane przez bibliotekę jako procent przychodów brutto;

- pozostałe źródła finansowania jako procent przychodów brutto;

- wydatki na zbiory jako procent wydatków na funkcjonowanie biblioteki;

- wydatki na drukowane książki polskie i zagraniczne jako procent wydatków na zbiory biblioteczne;

- wydatki na drukowane czasopisma polskie jako procent wydatków na zbiory biblioteczne;

- wydatki na drukowane czasopisma zagraniczne jako procent wydatków na zbiory biblioteczne;

- wydatki na zbiory specjalne jako procent wydatków na zbiory biblioteczne;

- wydatki na zasoby elektroniczne jako procent wydatków na zbiory biblioteczne;

- wydatki na sprzęt komputerowy i oprogramowanie jako procent wydatków na funkcjonowanie biblioteki;

- wydatki na wyposażenie jako procent wydatków na funkcjonowanie biblioteki;

20 Wzory obliczania wskaźników podano w: Wskaźniki funkcjonalności dla bibliotek szkót wyższych (2016 r.), dz. cyt. 
- wydatki na wynagrodzenia i inne świadczenia $\mathrm{z}$ tytułu pracy jako procent wydatków na funkcjonowanie biblioteki;

- wydatki na usługi i koszty administrowania jako procent wydatków na funkcjonowanie biblioteki;

- wydatki na szkolenie personelu jako procent wydatków na funkcjonowanie biblioteki;

- wydatki na utrzymanie pomieszczeń i remonty jako procent wydatków na funkcjonowanie biblioteki;

- wydatki na promocję jako procent wydatków na funkcjonowanie biblioteki;

- koszt amortyzacji jako procent wydatków na funkcjonowanie biblioteki;

- inne wydatki jako procent wydatków na funkcjonowanie biblioteki;

- budżet biblioteki jako procent budżetu uczelni;

- stosunek wydatków na gromadzenie i obsługę zbiorów do kosztów personelu;

- koszt w przeliczeniu na odwiedziny w bibliotece;

- koszt skorzystania ze zbiorów. 